\title{
MIR25 wt Allele
}

National Cancer Institute

\section{Source}

National Cancer Institute. MIR25 wt Allele. NCI Thesaurus. Code C81905.

The human MIR25 wild-type allele is located in the vicinity of 7q22.1 and is approximately 83 bases in length. This allele, which encodes MIR25 pre-miRNA, plays a role in the regulation of gene expression. Alteration in the expression of this gene is associated with the development of cancers of the liver and stomach as well as multiple myeloma. 